\title{
From Hunter to Protector: The Invention and Reinvention of the Nuri Talaud
}

\author{
Karno Batiran ${ }^{1,}{ }^{*}$, Micah R. Fisher ${ }^{2}$ \\ 1 Peasant School Network of PAYO-PAYO. Maros, South Sulawesi, Indonesia.karnobatiran@payopayo.or.id \\ 2 Universitas Hasanuddin, Faculty of Forestry. micah@unhas.ac.id \\ University of Hawaii, National Disaster Preparedness Training Center. micahrf@hawaii.edu \\ Affiliate Faculty at the Matsunaga Institute for Peace and Conflict Resolution \\ * Corresponding author
}

\begin{abstract}
This article describes the ways in which the Nuri Talaud, a small colorful bird located on an island at the northern reaches of Indonesia, first became a hunted commodity and evolved into a thriving protected species. Told from the life history of Om Zaka, a local hunter turned bird conservationist, this article describes the background that shaped the shifting values placed on the Nuri Talaud. The bird initially gained value as a symbol of the state through its selection for inclusion in Indonesia's national theme park. As a result of its newfound prominence, local hunters emerged to systematically hunt the bird for sale through a network of international species trade. Nearly facing extinction, various actors and initiatives came together to protect the Nuri Talaud. This paper shows the ways in which a species can be targeted to almost extinction, and the processes that can take shape to ensure its protection.
\end{abstract}

Keywords: Nuri Talaud (Eos histrio talautensis, Red-and-blue Lory); community-based conservation, invention of tradition; commoditization of nature; Wallacea; community based natural resource management (CBNRM); co-management

\section{Introduction}

Taman Mini Indonesia Indah (TMII), or the miniature park of Indonesia, was created as a nation building project in 1975 to bring together the many representations of Indonesia and display them in the capital, Jakarta. Most people experience TMII in the form of small islands built in the shape of Indonesia, and marketed as a theme park with cultural booths that tell the story of a culturally diverse but united Indonesia. Visitors can view and tour the traditional homes and experience various aspects from regions across the vast archipelagic nation. Lesser known about TMII however, is that the park was not only constructed as a cultural attraction, but also one that conveys the unique biodiversity of Indonesia. One major initiative in the construction of TMII involved collecting and displaying a select sample of unique living specimens to represent the vast endemism and exotic flora and fauna from across the country. In 1986, the final phase of the TMII project included the construction of the bird park.

At the northern reaches of Indonesia, on the island of Karakelang, North Sulawesi, a colorful red and blue Lory (henceforth described by the Indonesian common name, Nuri Talaud) was chosen for inclusion at TMII. It was not only chosen for its unique features, but also as a species found at the geographic boundaries of the state. The Nuri Talaud (Eos histrio talautensis, known locally as Sampiri) is only found on Karakelang island, and marks the boundaries of Indonesia's northern state borders with the Philippines. This bird was therefore chosen on the one hand for its exotic appearance, but also strategically as a marker for the furthest claims of the nation.

In this article we aim to describe how a virtually unknown bird species - even viewed as benign and largely ignored locally - took on an almost immediate role as a national symbol by its inclusion in TMII. Furthermore, though the Nuri Talaud came to serve as a symbol for national identity, the attention also created demand for the bird. It became a very lucrative commodity, particularly for a group of local hunters that were able to sell the bird through illicit networks of transboundary species trade. Over the next two decades, the bird neared extinction. However, the past 15 years 
have seen the bird rebound as a resulting of new narratives and practices that led to the revival and new species-society relations emerged. This paper describes from the perspective of the Nuri Talaud's fiercest hunter, became one of its most outspoken protectors. The paper therefore speaks to the importance of the forms of value - both of identity and commodity - in shaping communitybased conservation outcomes.

Indeed, most of the research tradition on conservation in the Wallacean region tends to focus on species distributions and counts (Fisher et al., 2020 - this issue), and this is especially true of Wallacean birds (White and Bruce, 1986). On the other hand, development projects for community conservation - numerous but fragmented - focus on the narrower requirements of project implementation (Li, 2016). Typically overseen by large donors or small NGOs, conservation and development initiatives must strategically navigate the formal approvals of the state, and usually require proponents to frame nonpolitical problems that require technical solutions (Ferguson, 1990; Li, 2007). As a result, only certain types of viable solutions emerge, which do not expose or address the underlying political ecologies that underpin conservation and development relations.

Alongside the other articles in this collection (Fisher et al., 2020 - this issue), this article is a call for more critical and historically situated perspectives, which also examine the intersection of identity formulation across people, landscapes, and species. One relevant example of such an approach from the Wallacea region is Zerner's (1994) formulation of the changing meanings and ideas of the environment through the revival of indigenous governing systems, the Sasi (see also Thorburn, 2000; Lowe, 2000). Zerner's approach takes from a broader literature on the invention of tradition and the processes of cultural transformation (Hobsbawm and Ranger, 1983). In this article we follow a similar approach. However, rather than examining the changing regional governing systems as identified by Zerner, this research highlights a more particular process surrounding the changing worldviews of the key negotiators of exploitation and protection of the species at its source. Using a life story approach (Peacock and Holland, 1993), we examine one hunter's story, not specific to the facts that unfolded, but rather for the meanings that they convey. Our focus is therefore around one of the most instrumental roles of exploitation and protection, namely the hunter-turned-protector of the Nuri Talaud.

The research is told through the life story of the first Nuri Talaud hunter, Zakaria Majuntu, or more commonly known as Om Zaka. From his beginnings of identifying the most efficient ways to hunt the Nuri Talaud, Om Zaka has since become one of its most influential and outspoken protectors. Through his voice, we examine Om Zaka and the Nuri Talaud's relational habitat, beginning with the invention of the bird as a national symbol circa 1986, the practices that he developed to capture and sell the bird as a commodity, through the various changes until the current conditions of strong values for protection. Of course, our research is not limited to a singular life story, but that the life story approach is also situated among the context we examined by studying the numerous development projects, activist initiatives, government regulations and policies, as well as reference with other key documents and data that further contextualize our approach. ${ }^{1}$ Furthermore, the hunter's narrative is not only examined through the eyes of Om Zaka, but also formed by a series of interviews with other former hunters and their families. In total, the research includes 15 targeted interviews, mostly with the families of former Nuri Talaud hunters, as well members of local NGOs and conservation projects from Yayasan Sampiri, KOMPAK, and IDEP foundation, which form the narrative of this research.

The paper proceeds as follows. The next section provides a geography of the Nuri Talaud, describing its basic features, habitat, range, region, as well as the key factors that shaped the bird's identification as a unique species. Thereafter we turn to what we describe as the first phase, namely

\footnotetext{
${ }^{1}$ The research also included document review of IDEP foundation and Yayasan Sampiri reports, as well as project monitoring and evaluation reports from Burung Indonesia.
} 
the factors triggering the emergence of hunters to exploit and sell the bird on the international market. The second phase then describes the transition of hunter to protector, examining the factors that made this transition possible. We then turn to a discussion on the shifting meanings the invention and reinvention - of a tradition about viewing the Nuri Talaud. We conclude by connecting our findings with the overall context of community conservation in the Wallacea region.

Figure 1. The Nuri Talaud [Eos histrio taulatensis / Red-and-blue Lory / Sampiri]

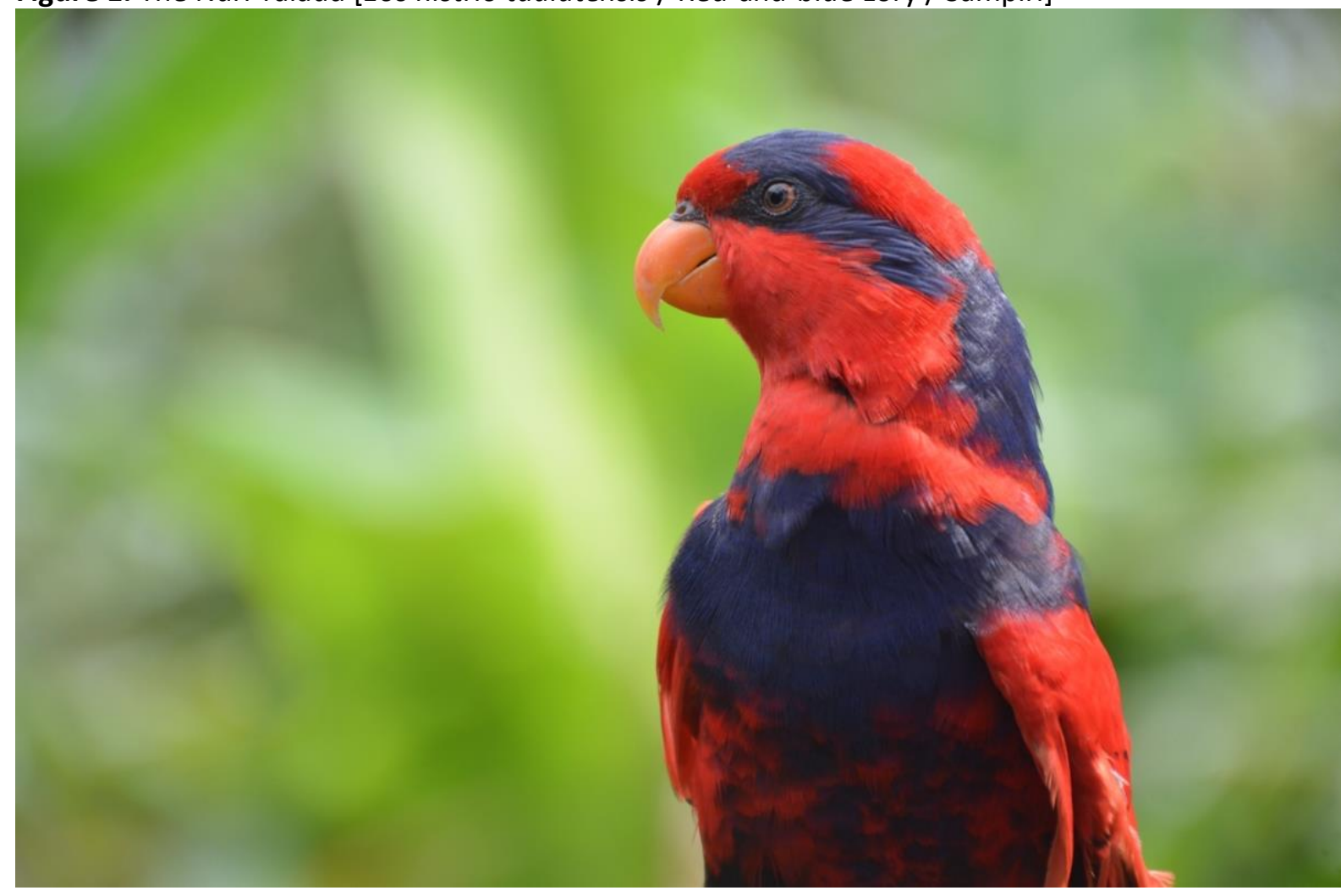

Photo Credits: Hanom Bashari / Burung Indonesia and IDEP Foundation

\section{The Geography of the Nuri Talaud}

The Talaud Islands district is situated between the Sulawesi sea and the Pacific Ocean in the northernmost part of North Sulawesi province, and borders the islands of Mindanao Philippines, which have a unique avifauna profile (White and Bruce, 1986; Riley, 2003). There are several groups of islands that are part of the Talaud Islands: the large island of Karakelang, the island of Kabaruan, the island of Salibabu, the cluster of islands of Nanusa, and the cluster of islands that are directly adjacent to Miangas, the Philippines (See Map 1). Karakelang is the largest island and the main center of activity, which is also the location of Melongguano, the capital of the Talaud Islands district. Although the largest of the Talaud Islands, Karakelang is still relatively small, amounting to only $975 \mathrm{Km} 2$. Karakelang Island is the only remaining location where the Nuri Talaud can live and breed.

The Nuri Talaud is one of the three subspecies of Eos histrio, namely: Eos histrio talautensis, Eos histrio and Eos histrio challengeri. The last two of these are believed to have gone extinct in nature. At present, only Eos histrio talautensis remains in the wild, and has become more broadly known as the Nuri Talaud, or under the English common name of the Red-and-blue Lory.

TMII began to commission the collection of the Nuri Talaud for the bird park in 1986. About 1,300 Nuri Talaud were ordered to be delivered from Karakelang island. Meeting the demand for the TMII bird park marked the beginning of systematically hunting the Nuri Talaud. A bird that was 
previously widespread but not considered to have much value locally, would over the years be pushed to the verge of extinction. The "discovery" of the Nuri Talaud as a marker of Indonesia's northernmost geographical boundaries and symbol of identity to be displayed as a representation of national pride in its nationalist theme park also marked another transformation for the Nuri Talaud. Some locals in Karakelang soon realized that the initial demand from TMII also triggered demand from elsewhere, thus initiating the bird's commoditization for potential lucrative income. 2

Since 1986, the Nuri Talaud became a popular bird traded both locally and internationally alongside other species from the Wallacea region, which include the broader category of parrots [burung paruh bengkok]. Just like other parrots and parakeets, the demand for Nuri Talaud began to increase, particularly because it is very easy to pet and tame. The bird is also viewed as highly intelligent, because it can mimic human voices. This particular Nuri also has soft and colorful feathers, and can live for a long time, anywhere from 50-80 years. The expansion of hunting and trade for the Nuri Talaud led to its listing in the IUCN CITES I as an endangered species in 1995. In 1999 the Nuri Talaud was also included in the list of animals protected by the Republic of Indonesia Government Regulation No. 7 of 1999 concerning the preservation of plants and animals. It is still listed as a threatened species (Birdlife International, 2016). The population of Nuri Talaud experienced a drastic decline in the 1990s. In 1995, it was estimated that only around 2,000 individuals species remained in the wild, but between 1992-1993, approximately 700 species remained (Yayasan Sampiri and Burung Indonesia, 2002). By the early 2000s however, Nuri Talaud populations began to recover, and was estimated at more than 8,200 species (Riley, 2003).

Besides direct threats from hunting and illegal trade, the Nuri Talaud also experienced habitat loss. The change in the Talaud Islands into a separate autonomous region from Sangihe to the Talaud Islands district resulted in development impacts to Nuri Talaud habitat areas. In becoming a district, the newly created administrative area also received additional allocation of funds for infrastructure development and construction. The new development pathways from becoming a new district resulted in extensive forest encroachment on Karakelang Island. Forest encroachment that came along with infrastructure development, and eliminated key areas important for the Nuri Talaud's natural habitat.

Another threat to the Nuri Talaud is due to the extensive use of pesticides on coconut plants that serve as a key commodity to local populations on Karakelang Island (Burung Indonesia, 2014). Most of the island's landscape is filled with coconut groves, forming the central cash economy among locals. Meanwhile, the Nuri Talaud's diet consists of extracting the nectar from flowers from various guava and durian species. The Nuri Talaud can also collect nectar from coconut flowers that they use for food, but the more intensive applications of pesticides has a direct effect on their health.

The administrative and land management status of Karakelang island has also changed over time. In 1997, Karakelang was designated as a hunting park. Soon after, in 2000, this status was reversed, designating it as a wildlife reserve area divided between the Northern Karakelang Wildlife Reserve and the Southern Karakelang Wildlife Reserve (Heropolo, 2019). The total area of the Karakelang Wildlife Reserve is 24,669 hectares. The status of forests on the island are designated as protection forests. In total, around $35 \%$ of Karakelang island is designated as a protected area. In addition to the nature reserve and protected forests, Karakelang consists of plantations and settlement areas. Most of the inhabitants of the islands are farmers and fishermen. The main commodities are coconut, cloves and nutmeg. According to the Indonesian Bureau of Statistics (BPS) data in 2018, the total population of the Talaud Islands is 90,678 people, of which 58,459 live on Karakelang (BPS Kepulauan Talaud, 2019).

\footnotetext{
${ }^{2}$ See also Nevins and Peluso (2008) for more on the commoditization of nature in Southeast Asia.
} 


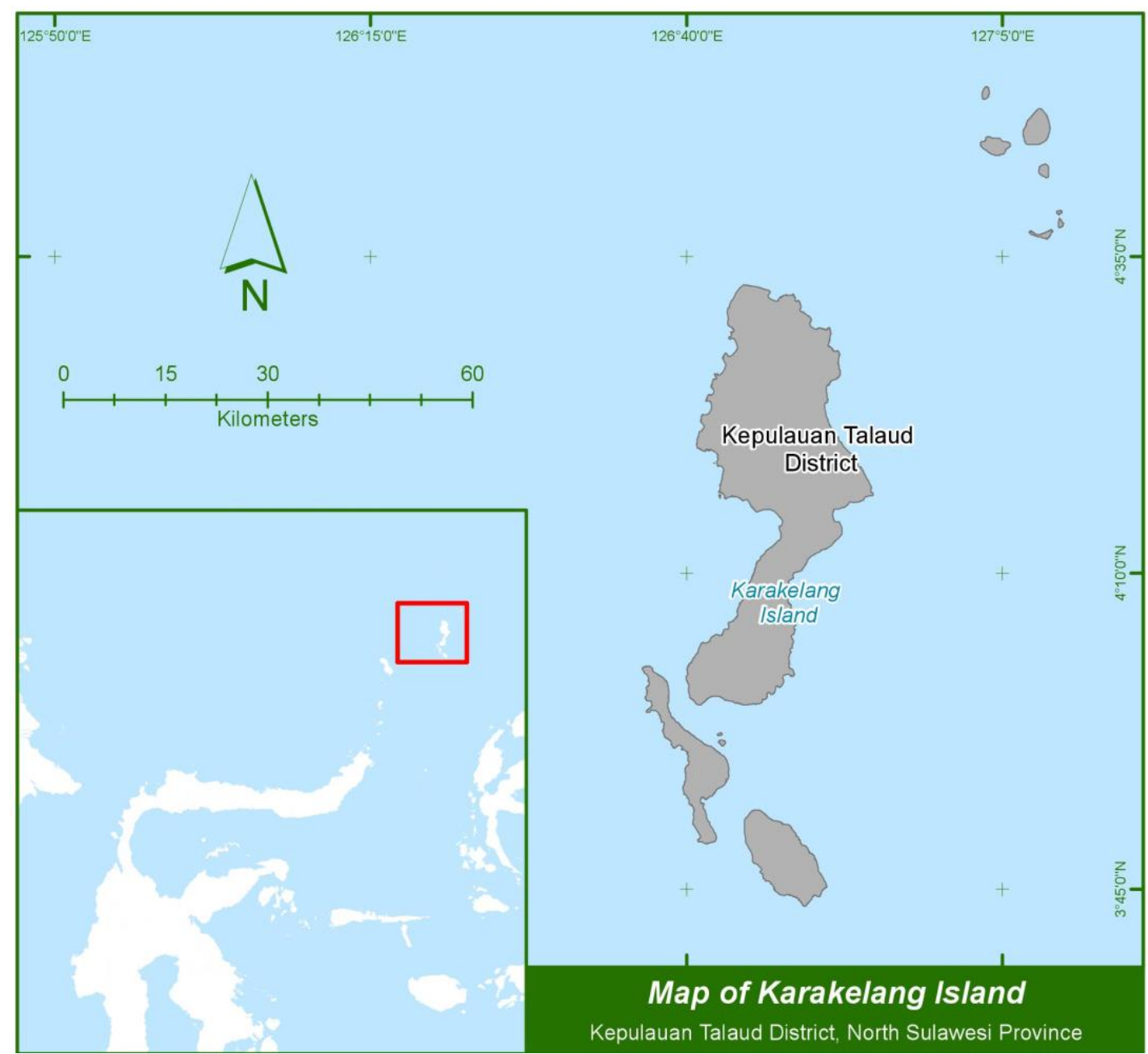

Figure 2. Karakelang Island

\section{Hunting the Nuri Talaud}

Om Zaka is from Bantane, a small village located on the Eastern coast of Karakelang Island, and about 11 kilometers from Beo, which was the former sub-district center of Talaud. It is another 36 kilometers from Melonguano, the capital of the Talaud Islands district. In 1986, Om Zaka met an employee from the Forestry Ministry's Directorate for Nature Conservation and Protection (Directorate PPA). Om Zaka described that this agency was tasked with the responsibility of bringing back a certain quota of Nuri Talaud to TMII. He described his experience and surprise when he interacted with the PPA employee, and that this individual was tasked with commissioning the capture of 1,300 live specimens. Om Zaka's encounter with the person was a mere coincidence, but intrigued, Om Zaka invited the PPA staff to visit his home. The PPA staff told Om Zaka the story of the request his agency had received, which was directed by Mrs. Tien Soeharto, the first lady of the Republic of Indonesia. Commanding extremely influential status during the authoritarian rule of President Suharto, a request by the first lady consisted of an extremely important assignment to be fulfilled. This information piqued Om Zaka's interest and he decided to offer his services to try to capture the Nuri Talaud to fulfil the agency's order. Om Zaka was also received an official permission letter by the PPA staff to undertake this task.

Because it was previously uncommon to hunt the Nuri Talaud at that time, Om Zaka did not yet 
know how he would collect the birds alive. He began to experiment with different ways of capturing the Nuri. He first identified their habitats, following their overall behavioral traits. He identified their resting locations, the way they gathered and sought out food, the times of the day they would take flight, and numerous other factors. During this pre-hunting period, Om Zaka's descriptions of the Nuri Talaud populations were such that they were so widespread on one area of Karakelang's coastal formation that the entire area would turn completely red in the afternoon, reflecting the color of the birds. Om Zaka began to experiment with making the right glue, which he produced through the sap of a breadfruit tree so as to capture the bird without harming it. Once he figured out the correct adhesive, he thereafter sought out different sites to place his traps. During his early experiments, he was immediately successful in capturing several birds.

The quota of fulfilling 1,300 individuals however, was still a sizable task given the number of birds Om Zaka could collect on a daily basis. Om Zaka began to recruit several friends from his village and other neighboring villages to join him. Every time he and the other hunters went to the forest, they returned with about 30-50 Nuri Talaud. On one occasion they even collected 100 birds in a day. Within three months, Om Zaka and his recruits were able to fulfil the quota set for TMII. After he had fulfilled the quota, Om Zaka viewed this work as easy money compared to his previous livelihood as a farmer. When we asked him how much money he made hunting the Nuri Talaud, he did not give his answer in monetary terms. Instead, he responded by saying that he was able to marry all five of his children from the income he collected from hunting the Nuri Talaud. Given that marrying one's child is a significant responsibility for a parent in Karakelang, requiring a significant investment, such a comparison equated to a successful career in fulfilling his duty to his family. Om Zaka felt a sense of great dignity and pride from his profession and success as a hunter.

After the initial TMII quota was fulfilled however, Om Zaka began sought out other opportunities to continue selling the live birds. A market had developed over the years among Filipino fisherman engaging in trade with Karakelang. The Filipino fisherman had long brought metal pans and machetes to barter for salt and kerosene available in Karakelang. When the fisherman heard about the potential value of the Nuri Talaud, they began to also purchase the birds from Om Zaka to sell them internationally. Over time, the trade became very lucrative and the supply chain more complex, with middlemen emerging to negotiate price exchanges between hunters and the Filipino traders.

There was a specific schedule to the trade. The Filipino traders always arrived at the same site in the Northwest area of the island, at Apam village, to buy and trade for the Nuri Talaud. At that time, each day Om Zaka set out for the forest setting traps to catch Nuri Talaud. Om Zaka's hunting area was not only around the village of Bantane, but as he became increasingly skilled as a hunter, he followed the Nuri Talaud behavior patterns and habits all over the island. From Riung and Tuabatu on the east coast of the island, to Kuma and Essang on the west coast, from Bowongbaru and Tule to the south of the island until Dapalan and Apan to the north, Om Zaka likes to say, he covered the entire island of Karakelang.

In the early periods hunting around the village of Bantane Om Zaka only needed to walk about 3 kilometers inland into the forest to find a flock of Nuri Talaud among the feeding and breeding trees. He would place the glue traps and collect the Nuri Talaud. After traveling further afield to hunt the Nuri Talaud, over time, Om Zaka recalled setting aside a full week for hunting trips. He commonly overnighted in the forest, returning home when he had secured his quotas. If the hunting sites were close to Apan village, the area that Filipino boats would dock to trade, Om Zaka would at times bring the captured birds directly to sell the birds himself. He noted that the demand among the Filipino traders never slowed. There was always an eager buyer.

In the early years of hunting through the late 1980s, Om Zaka easily collected up to 50 Nuri Talaud in one hunting trip. Om Zaka explains it as if he had beginner's luck when he first tried capturing Nuri Talaud to fulfil the TMII request. At that time, he recalls capturing more than 100 Nuri Talaud during his first few attempts. Om Zaka usually installed 2 to 4 glue-sticky-wood traps at 
one period. One trap could capture about 5-6 Nuri Talaud. In a given day Om Zaka set traps twice, morning and evening, and then collected the result from the traps at $10 \mathrm{am}$ and $3 \mathrm{pm}$. At that time Nuri Talaud was valued at around 2,000 to 5,000 rupiah (IDR) per individual. According to Om Zaka, Nuri Talaud requested for TMII was valued at IDR 2,000 per individual, which translates to as much as 80,000 to 100,000 IDR in current monetary value, or around 5 - 7 US dollars. If Om Zaka caught an average of 50 individuals of Nuri Talaud per each hunting expedition, then he could make around 100,000 IDR, a handsome sum for that time period. This would be equivalent to around 4,000,000 IDR (close to US\$300) in today's terms, a lucrative income for anyone in Karakelang. This type of income, according to Om Zaka, was also much easier for him to obtain, and much more profitable than the other economic options of that time, which featured an economy mostly around coconut farming.

Although Om Zaka recruited other associates during periods of peak demand, he normally hunted alone. Most of the other hunters worked in pairs or in a group of three. Om Zaka with his "pupils," as he recalls them, included 8 individuals who he instructed on the ways of capturing the Nuri Talaud. He showed them how to use the glue from the sap of the breadfruit tree, smearing it on the tree branches frequented by the Nuri Talaud. This approach was different from other hunters, which included using nets.

As hunting continued as a business beyond the TMII request, the Nuri Talaud were also sold to local security personnel (Babinsa) that emerged as collectors and middlemen. They coordinated the sale to Filipino traders docked in Apan village. The Filipino fishermen, while anchoring in Apan to refuel and refill with fresh water and reload on other key logistics and materials, also set up their trade with the local people of Karakelang on the side. Local residents bartered and sold soap, salt and kerosene, while Filipino fishermen traded for metal pans, machetes, salted fish, and other commodities. The Nuri Talaud also entered into the equation of these exchange markets. The difference is that collectors, usually paid for Nuri Talaud with cash.

Table 1. The different phases, characteristics, and conditions of the Nuri Talaud

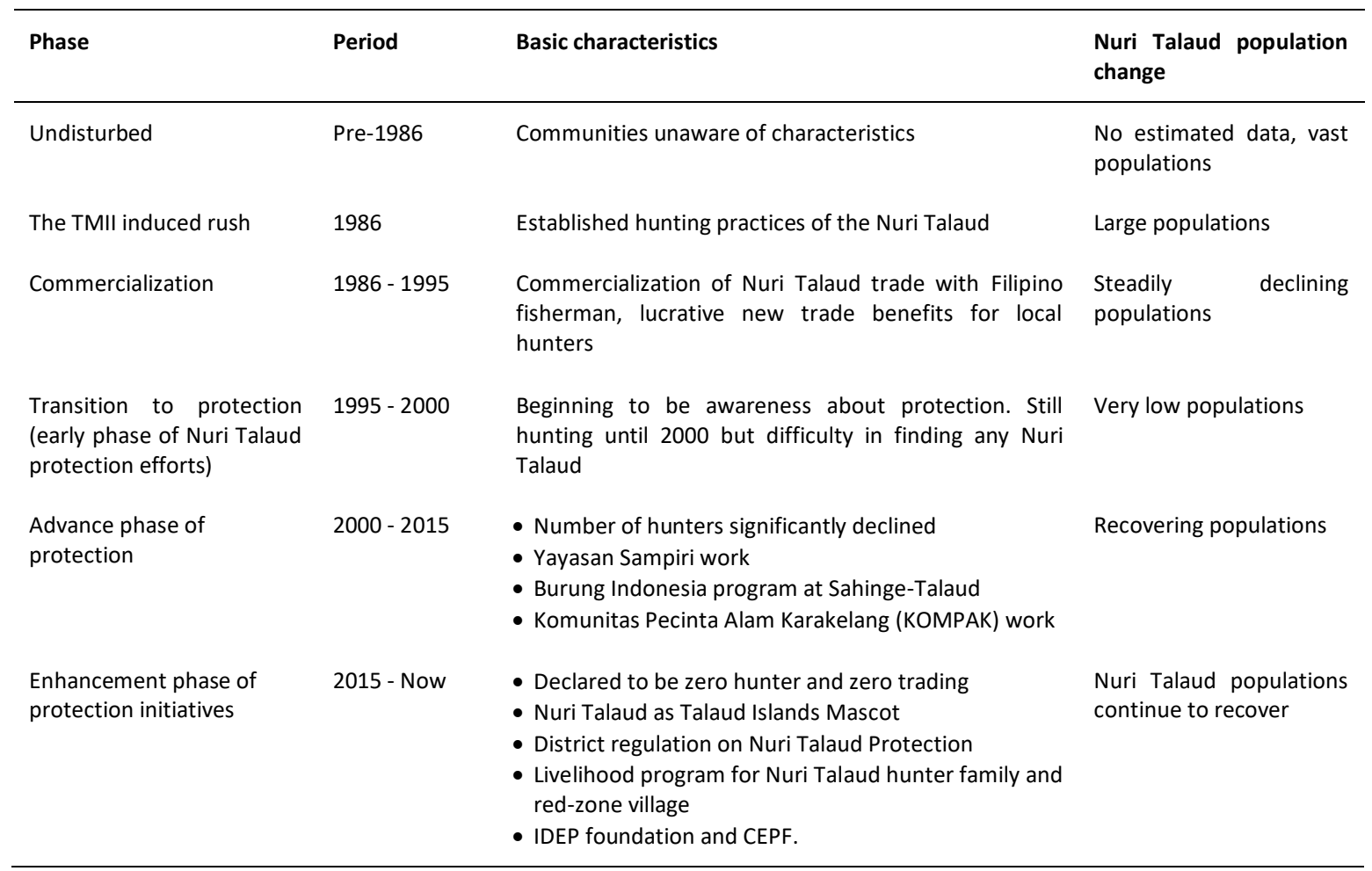

The contacts between fishermen and Filipino traders was a longstanding one, with extensive 
interaction across state borders between the people of Sangihe and Talaud. Traders from SangiheTalaud also smuggled copra - a commodity from the coconut groves - into the Filipino and Malaysian markets, depending on prices. Unsurprisingly, one informant discussed the important social relationships that also developed across these state boundaries, consisting of cross-border marriages between the Sangihe-Talaud peoples.

When the promotion of programs to address illegal wildlife trade were instated, such as monitoring and patrols particularly against the illegal trade of Nuri Talaud, the Filipino fishing vessels no longer anchored in the village of Apan. The cracking down against these trading networks also had a broader social impact of disconnecting regular family interactions fused through these trading networks. Any transactions during such conditions, were made on the open sea. After years of hunting and trading however, the population of Nuri Talaud - and the supply for the trade drastically declined. At one point, hunters were going to the forest unsuccessful in catching a single individual of Nuri Talaud. Table 1 provides a general description of how Nuri Talaud populations declined relative to the various time periods.

\section{The Transition from Hunters to Protectors}

The beginning of Nuri Talaud conservation efforts began with a research project conducted by five researchers from York University and Leeds University, both institutions based in the UK. The research began in 1995 whereby the researchers visited Kabupaten Kepulauan Sangihe Talaud3 to conduct biodiversity research. During their visit, the Nuri Talaud caught their attention and became a specific focus of their research. The researchers identified the species not only because of its endemism as a unique species to the Sangihe-Talaud Islands, but also because of the widespread hunting and illegal trade posing significant threats to the bird. In the course of the study, the foreign research team identified that the Nuri Talaud was experiencing serious threats from poaching and illegal trade and with a consortium of local partners an effort emerged to do something to save the bird. Attempts to include Nuri Talaud hunters in assisting research became the starting point for organizing hunters and the turning point of transformation from hunter to protector of Nuri Talaud. Knowing the habitats best, the hunters were invited to serve as guides and served as the key informants. The hunters helped to identify the habitats, breeding and feeding areas, ranges and other key information related to species behavior. One of these hunters was Om Zaka.

The arrival of the foreign researchers in Sangihe-Talaud marked the beginning of the local Sampiri action program, which began as a network of young people interested in conservation. Some of the proponents were local students that had worked with the foreign research team. After the first research was conducted in 1995, York University researchers returned the following year. The foreign research team again partnered with local researchers and students from the faculty of agriculture at Sam Ratulangi University in North Sulawesi. The Sampiri action program thus began as a local species survey program and community education initiative focused on the Nuri Talaud. The education team conducted an awareness raising campaign, convened discussions and outreach programs on the importance of Nuri Talaud, helped in the status identification of the Nuri Talaud, and documented the overall story of the bird, which they identified as only living on Karakelang Island. Their campaign was far reaching, carried out in schools and churches and across the communities of Karakelang Island. This initiative also began to grow pride about the endemic species to the Talaud islands. It was framed as something that only they owned, that was nationally recognized, and that without intervention, could be lost forever. Sampiri's interventions took place between 1996-1998.

Meanwhile, the period of Om Zaka's transition to active involvement in conservation efforts began in parallel. An engaging and outspoken personality, working with Sampiri, Om Zaka began to

\footnotetext{
${ }^{3}$ At that time Talaud and Sangihe were still one district
} 
get involved in education activities on Nuri Talaud protection. He was enlisted into the "Key Forest Conservation Program" supported by Burung Indonesia, a program established to work on conservation in the Sangihe-Talaud Islands. Om Zaka continues to be actively involved as a local contact and serves as one of the main informants in the Nuri Talaud's awareness raising campaign. From his pioneering work as a hunter, in a short period of time, Om Zaka had become one of the most progressive proponents of conservation. Part of this had to do with the decline of the bird populations and the increased enforcement by authorities, but more so, the transition to protector emerged around the changing meanings associated with the bird and its inherent value.

In 1999, the Sampiri action program group began a new phase of exploring the forests of Karakelang island, identifying Nuri Talaud habitats and collecting data about the bird's characteristics. They identified where the Nuri Talaud rested, their feeding areas, and other features of their behavior. Om Zaka was among the group. While the Sampiri action program conducted their fieldwork, they interacted with local villages, collecting and sharing information about their research. Their approach also viewed the community level grassroots engagement as part of their broader campaign strategy, seeking to fulfill objectives of educating and raising awareness about the endangered Nuri Talaud. During this overall engagement with local people in Karakelang, Om Zaka became the main resource person and facilitator.

Nuri Talaud conservation efforts continued beyond the Sampiri action program. Many among the group of young people involved in carrying out the field research for the Sampiri action program came together and formed an organization dedicated to Nuri Talaud conservation. The organization was named the Sampiri Foundation. For the past two decades, Nuri Talaud conservation efforts continue to be facilitated by the Sampiri Foundation. They have also continued to involve former hunters in their programming. During the initial periods of Nuri Talaud research, identification and data of hunters were collected at villages on Karakelang Island. The Sampiri Foundation continues to conduct awareness raising campaigns to churches, schools and communities throughout Karakelang Island. They continue to engage Om Zaka and other hunters as the main storytellers for Nuri Talaud campaign events.

During the research phase of the action program, these hunters gained knowledge from their involvement in the research process, which subsequently changed their views, values, and behavior towards the Nuri Talaud. This new knowledge made them recognize the near-extinction and potential fate of the bird, which was matched with a sense of pride about something that was only located in their island. Their participation in the campaigns and raising awareness by acting as the main storytellers about the Nuri Talaud also increased their stake in protecting the bird, and their eagerness in being part of the process.

The subsequent phase of Nuri Talaud conservation efforts began during the arrival of a new phase of the Burung Indonesia project in Sangihe-Talaud. Burung Indonesia entered Karakelang to continue supporting existing initiatives and to reinforce Nuri Talaud conservation efforts that had been carried out for 7 years hence. They built upon initial Nuri Talaud research by British Universities in 1995, followed by the Sampiri action program in 1996-1998, and subsequent follow up efforts supported by the Sampiri Foundation in 1999-2001. Burung Indonesia conservation efforts began to focus on habitats in a program entitled "The conservation of key forests in the Sangihe-Talaud Islands." The project promoted a similar approach to previous efforts, by working closely with local communities and engaging specifically with former hunters. Nuri Talaud data collection continued alongside educational programs for raising awareness. In addition, the program partnered with local government institutions, trained forest agency staffs, and worked with the Forestry Ministry's natural conservation agency (BKSDA). Similar to previous efforts, former Nuri Talaud hunters continued to be involved, and at this point they had long ended their hunting practices.

Formal efforts however, slowed after the completion of the Burung Indonesia program. A new generation emerged to follow up on conservation responsibilities, consisting of a group of young students and researchers from Sam Ratulangi University. Some of them had served as research 
assistants in the previous programs, and established their ongoing activities under the banner of a new conservation organization called Kelompok Pecinta Alam Karakelang (KOMPAK) [Nature Lovers Club of Karakelang]. Using a similar approach as previous programs, this group continued to involved former hunters, working with them to conduct outreach and education activities, raise awareness, and now working with the government (BKSDA) to conduct patrols, monitoring wildlife trafficking, and conducting forest rehabilitation programming.

These former hunters have also begun to facilitate village networks for conservation, which are locally called Kelompok Pecinta Alam Desa (KPAD) [village-level nature lover groups]. These groups are given the responsibility to conduct Nuri Talaud conservation efforts around the village, which include facilitating participatory planning and decision-making processes by the local people. Alongside actively supporting Nuri Talaud conservation efforts, they also conduct population data collection, mapping roosting trees, feeding areas, and tracking other behavior patterns. This also takes place with strategic tree planting activities and forest rehabilitation in and around the village area. Indeed, this final step has included a more active handover towards local key persons, particularly among the ex-hunters, to maintain broader stewardship of conservation efforts.

At present time, supports from external conservation initiatives are transitioning into the enhancement phase. After successfully supporting the transition of hunters to protectors, programmatic efforts are seeking to ensure that former hunters do not return to hunting. Such programs are especially geared towards improving livelihoods that do not pose a threat to Nuri Talaud habitat. Several efforts include KOMPAK and IDEP foundation projects supported by Critical Ecosystem Partnership Funds (CEPF), conducting livelihood programs with villagers with the main target of working with ex-hunters and their families in the red-zone villages (the main Nuri Talaud hunter villages). Other efforts also include internalizing the Nuri Talaud as a source of identity and pride, such as a mascot, so that people will believe they are hurting themselves and their communities if they have negative impacts on the Nuri Talaud.

\section{Discussion}

There are many ways to understand the changing processes that took place with the Nuri Talaud. In particular, the bird went from an unknown species to a national symbol, then to a valuable commodity of transnational illegal species trade, and finally to a species protected by various groups. Before the mid 1980s, the Nuri Talaud did not gain much attention, from locals or elsewhere. However, due to the decision to include the Nuri Talaud in the TMII theme park - the bird was marked for its position as a boundary of the state and a hardening symbol of the Indonesian nationstate - the bird came to be part of the larger narratives fused to Indonesian identity. This is a fine example of what Hobsbawm and Ranger (1983) famously called the invention of tradition. Through displaying the bird in the national capital, it emerged as one important descriptor of Indonesian nation-state identity, indeed another element in the representation of unity and diversity. This process brought yet another way for staking claims to the remote areas at the boundaries of its control into the purview of the Indonesian state. In TMII, Indonesian identity was showcased through the collected cultural monuments and tradition, such as through cultural dances and rituals, symbols of ethnicity and biodiversity from across the archipelago. The Nuri Talaud became part of this story of nation and identity.

Meanwhile however, the creation of the Nuri Talaud as a symbol of identity also converged with the creation of value around the bird. Nevins and Peluso $(2008 ; 2018)$ have described the way that commoditization of nature has taken root in unlikely and surprising ways. Whereas before 1986 the people of Karakelang placed no intrinsic value of the Nuri Talaud, afterwards, it was identified as a national symbol and exoticized as a unique object that also began to generate an economic value. Hunters began to make a livelihood capturing the bird, and middlemen traded it to fishermen and traders from across international waters. State actors also played a role in facilitating this 
economy as officials filled the role as middlemen. This translated into an economic demand and financial value around the bird that resulted in transnational trade networks emerging to transport the bird to unlikely places around the world.

Interestingly however, within a short period of time commoditization evolved into conservation. As the bird populations decreased, it gained international attention. Thereafter, a network of research coalitions from the UK connected with the regional university and local populations to try to raise awareness about protecting the Nuri Talaud. A unique part of their approach was to work with local hunters as those most knowledgeable about the bird's habitat as the key actors to help protect it. Together, this multi-scalar network of key actors established a new tradition about the bird and its value. The empirical material presented in this paper has centered around these networks, particularly around Om Zaka's life story that connects between each of the three phases, from the TMII Collection efforts, to the commoditization stage, and finally as one of the key advocates during the conservation stage.

Nuri Talaud conservation efforts were unique and largely successful because of their approach. Proponents committed to directly involving the hunters and those responsible for the illegal trading of the Nuri Talaud. Their efforts on Karakelang reached a point whereby hunting activities had ceased entirely. The transformation of hunters to active players in conservation efforts to protect Nuri Talaud has clearly been a key factor for the rebounding populations of the Nuri Talaud. Om Zaka, the original hunter continues Nuri Talaud protection efforts, and is outspoken about taking part in education programming about the importance of protecting the bird.

For community conservation, the research herein highlights not only the importance of a broader coalition for conservation that can shape a new tradition about a species to ensure its protection. It further hones in on the greatest threat to the species existence. Two key elements are salient for involving hunters in becoming conservationists. The first relates to the active involvement and encouraged participation of hunters in the research process. Indeed, the researchers aptly identified that hunters new best about the habitats of the Nuri Talaud. Meanwhile, involving hunters as knowledgeable actors in the research allowed for a sense of pride to emerge about their knowledge of the bird. It also highlighted the hunters' ability to contribute to protecting what they began to sense had a new intrinsic value. Second, by involving them as the main storytellers about the Nuri Talaud helped to spread awareness and educate the broader public about protection efforts and at the same time extended the responsibility to them for protecting not only the Nuri Talaud, but also working to similarly protect their habitats.

\section{Conclusion}

The transition of hunters to protectors provides a unique lesson for other places facing conservation of endangered wildlife trade. In looking back at the story of Om Zaka and the hunters turned protectors, it is evident how a species that faced near extinction began to rebound. Rather than focusing on the species alone, local initiatives supported by external resources worked with community capacity and interests, centering engagement around transforming the role of the hunters as the actors that had the largest direct impact on the Nuri Talaud, which were at once the ones that had the most direct knowledge about the bird's habitat and characteristics. The implementation of these initiatives also involved participation of the community at large, involving them in a visioning process from planning to decision making. As a result, a new tradition about the bird was invented, one that not only would no longer accept hunting the bird, but also actively sought to improve its overall habitat.

However, by no means are the current outcomes of Nuri Talaud conservation automatic. In pressing economic conditions, there are likely others that would be willing to take up a lucrative, though illicit activity. Particularly with enticing lucrative demand do not necessarily protect against a return to hunting, particularly as generations change and new ideas about the bird and its 
environments change. Indeed, prior to its selection for inclusion at TMII, the bird was invented as a national symbol resulting in its commoditization and resultant trade. Similarly, through a series of sustained efforts that spanned international researchers, regional conservationists, and involving key local actors triggered new ideas tied to local pride about the species that led to new invented tradition of working towards ensuring the Nuri Talaud's protection.

The bird was initially identified as a symbol of the boundaries of the state. Now it is a regional mascot for protection and conservation associated with regional identity and pride. The future symbols of the bird and its role in society could result in new pressures on its existence, such as in the forms of habitat destruction or otherwise. Community based conservation has emerged as the political concept of the region, strengthened by the buy in among those that presented the greatest threat to the bird. At the moment, it seems the tradition of Nuri Talaud conservation is here to stay. But ensuring that this tradition remains will require sustained initiatives around the Nuri Talaud, continuing to cultivate value of the bird and its habitat for protection.

\section{Acknowledgement}

The research was supported by the Critical Ecosystem Partnership Fund (CEPF) through Burung Indonesia. However, this paper solely represents the view of the researchers, and not necessarily those of CEPF. The writing process was assisted by Forest and Society. Review and feedback by the Wallacea special section team has been very valuable in developing and improving the ideas for this article. The researchers also thank Om Zaka and other former hunters, as well as the other local informants that generously provided their time to engage in the discussions of this research.

\section{References}

BPS Kepulauan Talaud. (2019). Kabupaten Kepulauan Talaud Dalam Angka 2019. Badan Pusat Statistik Kepulauan Talaud.

Birdlife International. (2016). Eos histrio. The IUCN Red List of Threatened Species 2016:e.T22684502A93032979. doi: http://dx.doi.org/10.2305/IUCN.UK.20163.RLTS.T22684502A93032979.en.

Burung Indonesia. (2014). Ecosystem Profile Wallacea Biodiversity Hotspot. Bogor. Burung Indonesia.

Ferguson, J. (1990). The Anti-Politics Machine: "Development," Depoliticization, and Bureaucratic Power in Lesotho. University of Minnesota Press

Fisher, M. R., Verheijen, B., Sahide, M. A. K., (2020) Introduction to the Special section: Establishing the ASLI framework, identifying emerging issues, and envisioning horizons of community conservation research in the Wallacea Region. Forest and Society 4(1).

Hobsbawm, E. J., \& Ranger, T. O. (1983). The Invention of tradition. Cambridge. Cambridge University Press.

Heropolo. (2019). North Karakelang Wildlife Reserve . Indonesian Forest. https:///indonesianforest.or.id/north-karakelang-wildlife-reserve/ . Accessed in 29 Jun. 2019.

Li, T.M. (2007). The Will to Improve: Governmentality, Development, and the Practice of Politics. Duke University Press, 2007.

Li, T.M. (2016). Governing Rural Indonesia: Convergence on the Project System. Critical Policy Studies 10(1), 79-94. doi: https://doi.org/10.1080/19460171.2015.1098553

Lowe, C. (2000). Global markets, local injustice in Southeast Asian seas: the live fish trade and local fishers in the Togean Islands of Sulawesi. People, plants, and justice: the politics of nature conservation. Columbia University Press, New York, New York, USA, 234-258.

Nevins, J., \& Peluso, N. L. (2008). Introduction: Commoditization in Southeast Asia. Taking Southeast Asia to market: Commodities, nature, and people in the neoliberal age, 1-26. 
Nevins, J., \& Peluso, N. L. (Eds.). (2018). Taking Southeast Asia to market: Commodities, nature, and people in the neoliberal age. Cornell University Press.

Peacock, J. L., \& Holland, D. C. (1993). The narrated self: Life stories in process. Ethos, 21(4), 367383. Retrieved February 8, 2020, from www.jstor.org/stable/640577

Riley, J. (2003). Population sizes and the conservation status of endemic and restricted-range bird species on Karakelang, Talaud Islands, Indonesia. Bird Conservation International, 13(1), 5974. doi: https://doi.org/10.1017/S0959270903003058

Thorburn, C. C. (2000). Changing customary marine resource management practice and institutions: the case of Sasi Lola in the Kei Islands, Indonesia. World Development, 28(8), 1461-1479. doi: https://doi.org/10.1016/S0305-750X(00)00039-5

White, C. M. N., \& Bruce, M. D. (1986). The birds of Wallacea:(Sulawesi, The Moluccas and Lesser Sunda Islands, Indonesia): and annotated check-list. British Ornithologists' Union.

Yayasan Sampiri and Burung Indonesia. (2002). Perdagangan Burung Paruh Bengkok di Pulau Karakelang, Talaud, Indonesia. Laporan teknis No 5-2002. Melongguano. Yayasan Sampiri and Burung Indonesia.

Zerner, C. (1994). Through a green lens: The construction of customary environmental law and community in Indonesia's Maluku Islands. Law \& Soc'y Rev., 28, 1079. https://www.jstor.org/stable/3054024 . Accessed in 29 Jun. 2019. 